\title{
STRATEGI PENCAPAIAN TUJUAN-TUJUAN AFEKTIF DALAM PENDIDIKAN AGAMA ISLAM
}

\author{
Oleh: Ridwal Trisoni*
}

\begin{abstract}
The teaching of Islamic education school/ madrasah still faces some problems up to present. Among the problems are: Learning orientation still emphasizes cognitive aspect, cooperation between teachers of Islamic education subject and other teachers has not been well developed, methods of learning tends to be monotonous, and the like. As a result, the goals of Islamic education subject which should focus more on affective aspects seems to be ignored. Consequently, many students know much about Islamic education subject but they know very little about the implementation in real life. In order that the affective goal of Islamic education subject can be realized, various strategies are urgently reeded. Among those strategies, beside teaching the subject in isolated way, integrating to all subjects, creating religions atmosphere within the schools/madrasah, and societies are bighly recomm ended ones
\end{abstract}

Kata kunci: strategi, afektif, nilai, ahklak

\section{PENDAHULUAN}

$\mathrm{D}$ alam Undang-Undang No. 20 Tahun 2003 tentang Sistem Pendidikan Nasional Pasal 3 dijelaskan bahwa Pendidikan Nasional berfungsi mengembangkan kemampuan dan membentuk watak serta peradaban bangsa yang bermartabat dalam rangka mencerdaskan kehidupan bangsa, bertujuan untuk berkembangnya potensi peserta didik, agar menjadi manusia yang beriman dan bertaqwa kepada Tuhan Yang Maha Esa, berakhlak mulia, sehat, berilmu, cakap, kreatif, mandiri, dan menjadi warga negara yang demokratis serta bertanggung jawab.

Tujuan Pendidikan Nasional tersebut sejalan dengan tujuan Pendidikan Agama Islam, yaitu meningkatkan keimanan, pemahaman, penghayatan, dan pengamalan peserta didik tentang agama Islam, sehingga menjadi manusia muslim yang beriman dan bertaqwa kepada
Allah Swt, serta berakhlak mulia dalam kehidupan pribadi, bermasyarakat, berbangsa dan bernegara (Muhaimin, 2004:78).

Kedua rumusan tujuan pendidikan di atas sangat syarat dengan pembentukan sikap, akhlak dan nilai-nilai (afektif) di samping aspek pengetahuan (kognisi) dan keterampilan/pengamalan (psikomotorik). Rumusan tujuan Pendidikan Agama Islam tersebut mengandung pengertian bahwa proses pendidikan agama Islam yang dilalui dan dialami peserta didik di sekolah/madrasah dimulai dari tahapan kognisi, yakni pengetahuan dan pemahaman siswa terhadap ajaran dan nilai-nilai yang terkandung dalam ajaran Islam, untuk selanjutnya menuju ke tahapan afeksi, dimana terjadinya proses internalisasi ajaran dan nilai Islam ke dalam diri peserta didik, dalam arti menghayati dan meyakininya. Melalui tahapan afeksi tersebut diharapkan dapat

* Poenulis adalah Lektor dalam Mata Kuliah Pendidikan Islam STAIN Batusangkar 
tumbuh motivasi dalam diri siswa dan tergerak untuk mengamalkan dan mentaati ajaran Islam (psikomotorik) yang telah diinternalisasikan dalam dirinya. Dengan demikian akan terbentuk manusia muslim yang beriman, bertaqwa dan berakhlak mulia. Untuk itu perhatian terhadap pembentukan sikap (afektif) dalam Pendidikan agama Islam di madrasah dan sekolah perlu menjadi perhatian oleh pendidik.

Selama ini praktek pembelajaran Pendidikan Agama Islam di sekolah /madrasah masih banyak mengalami kelemahan.Muchtar Buchari menilai pendidikan agama masih gagal (Muhaimin, 2005:23). Kegagalan ini karena praktek pendidikan agama Islam yang hanya berorientasi pada aspek pengetahuan (kognitif) daripada pertumbuhan kesadaran nilai-nilai Islam, dan mengabaikan pembinaan aspek afektif dan psikomotor. Kondisi ini mengakibatkan terjadinya kesenjangan antara pengetahuan dan pengamalan. Pendidikan Agama kurang concern terhadap persoalan bagaimana mengubah pengetahuan agama yang bersifat kognitif menjadi "makna" dan "nilai" yang perlu diinternalisasikan dalam diri peserta didik, untuk selanjutnya menjadi sumber motivasi untuk mengamalkan ajaran Islam dalam kehidupan sehari-hari.

Merebaknya isu-isu moral dan akhlak di kalangan masyarakat terutama generasi muda seperti penggunaan narkoba, tawuran pelajar, anarkisme, pelacuran, pembunuhan, pergaulan bebas, korupsi dan sebagainya sudah menjadi masalah sosial bangsa yang sampai saat ini masih belum ada solusinya secara tuntas. Kondisi ini tentu saja sangat memprihatinkan kita bersama kerena terkait dengan pembentukan kepribadian bangsa yang sangat dibutuhkan dalam pembangunan bangsa untuk bisa sejajar dengan bangsa-bangsa yang telah maju dan sejahtera lainnya. Banyak orang berpandangan bahwa kondisi demikian diduga bermula dari apa yang dihasilkan oleh dunia pendidikan. Pendidikanlah sesungguhnya yang paling besar memberikan kontribusi terhadap situasi ini, termasuk Pendidikan Agama Islam. Meskipun kondisi krisis akhlak dan moral ini bukan semata-mata disebabkan oleh kegagalan Pendidikan Agama Islam, namun bagaimana para pendidik bisa mencari solusi lewat pengembangan strategi-strategi pembelajaran Pendidikan Agama Islam yang lebih berorientasi pada pendidikan nilai dan akhlak (afektif).

Untuk itu dalam tulisan ini penulis mencoba menawarkan beberapa strategi dalam pencapaian tujuan-tujuan afektif dalam Pendidikan Agama Islam, sehingga peserta didik yang akan menjadi tumpuan bangsa ke depan tidak sekedar memiliki pengetahuan agama semata, tetapi lebih pada penanaman sikap (nilai) ajaran Islam dan pengamalannya.

\section{HAKIKAT PENDIDIKAN NILAI DAN SIKAP}

Sikap (afektif) erat kaitannya dengan nilai yang dimiliki seseorang. Sikap merupakan refleksi dari nilai yang dimiliki. Untuk itu, pendidikan sikap pada dasarnya adalah pendidikan nilai (Wina Sanjaya, 2006:272).

Nilai menurut Milton Rokeach dan James Bank adalah "suatu tipe kepercayaan yang berada dalam ruang lingkup sistem kepercayaan dimana seseorang bertindak atau menghindari suatu tindakan, atau mengenai sesuatu yang pantas atau tidak pantas dikerjakan (HM.Chabib Thoha, 1996:60).

Pengertian di atas memperlihatkan bahwa nilai merupakan sifat yang melekat pada sesuatu (sistem kepercayaan) yang berhubungan dengan subjek yang memberi arti (yakni manusia yang meyakininya).

Sedangkan pengertian nilai menurut J.R.Frankel adalah " a value is an 
idea a concep about what some one thinks important in life. (HM Chabib Thoha:1996:60) Lebih lanjut ia mengemukakan beberapa ciri tentang nilai sebagai berikut.

a. Nilai adalah suatu konsep yang tidak berada dalam dunia empirik, tetapi di dalam pikiran manusia.

b. Nilai adalah standar perilaku, ukuran yang menentukan apa yang indah, apa yang efisien, apa yang baik, apa yang buruk dan sebagainya. Sebagai standar, nilai merupakan pedoman untuk menentukan pilihan. Antara lain menentukan jenis tindakan atau perbuatan apa yang patut dilakukan. Standar perbuatan seperti itu disebut nilainilai moral yang menuntun seseorang untuk berbuat sesuatu tentang apa yang dianggap benar dan layak.

c. Nilai itu direfleksikan dalam perbuatan atau perkataan. Nilai itu sangat abstrak dan menjadi konkrit bila seseorang bertindak dengan cara tertentu.

d. Nilai itu merupakan abstraksi atau idealis manusia tentang apa yang dianggap paling penting dalam hidup mereka. Karena itu, nilai dapat dibandingkan, dipertentangkan, dianalisis dan didiskusikan, serta digeneralisasikan. Pada pihak lain, nilai juga memiliki demensi emosional. Nilai tidak hanya sesuatu yang idealis, tetapi juga merupakan komitmen emosional yang kuat. (W.Gulo, 2002:148)

Sementara Sidi Gazalba mendefinisikan "nilai adalah sesuatu yang bersifat abstrak, ia ideal, nilai bukan benda kongkrit, bukan fakta, tidak hanya persoalan benar dan salah yang menuntut pembuktian empirik, melainkan soal penghayatan yang dikehendaki dan tidak dikehendaki, disenangi dan tidak disenangi (Thoha,1996:60). Nilai adalah serangkaian sikap yang menimbulkan atau menyebabkan pertimbangan yang harus dibuat untuk menghasilkan suatu standar tertentu atau serangkaian prinsip dengan aktifitas dapat diukur (Abdul Somad:2006)

Dari beberapa pengertian nilai tersebut dapat diketahui bahwa nilai adalah suatu konsep yang berada dalam pikiran manusia yang sifatnya tersembunyi, tidak berada di dalam dunia empiris. Nilai berhubungan dengan pandangan seseorang tentang baik dan buruk, indah dan tidak indah, layak dan tidak layak, adil dan tidak adil dan sebagainya. Pandangan seseorang tentang semua itu tidak bisa diraba, hanya mungkin dapat diketahui dari perilaku yang bersangkutan. Nilai pada dasarnya standar perilaku, ukuran yang menentukan atau kriteria seseorang tentang baik dan tidak baik, indah dan tidak indah dan sebagainya, sehingga standar itu yang akan mewarnai perilaku seseorang. Dalam terminologi Islam nilai moral lebih familiar dengan istilah akhlak.

Namun demikian, seseorang dikatakan memiliki sikap/nilai, akhlak atau moral jika mereka memiliki kesadaran akhlak dan moral yaitu dapat menilai hal-hal yang baik dan buruk, hal-hal yang boleh dilakukan dan tidak boleh dilakukan serta hal-hal yang etis dan tidak etis. Remaja yang berakhlak dan bermoral dengan sendirinya akan tampak dalam penilaian atau penalaran moralnya serta pada perilakunya yang baik, benar dan sesuai dengan etika (Selly Tokan dalam Asri Budiningsih:2004:5) Artinya ada kesatuan antara penalaran moral/ akhlak dengan perilaku moral dan akhlaknya.

Menurut Paul Suparno ,dkk.untuk memiliki moralitas/akhlak yang baik dan benar, seseorang tidak cukup sekedar telah melakukan tindakan yang dapat dinilai baik dan benar. Seseorang dapat dikatakan sungguh-sungguh bermoral apabila tindakannya disertai dengan keyakinan dan pemahaman akan kebaikan yang tertanam dalam tindakan tersebut. (Asri Budiningsih:2004:2) Untuk dapat memahami dan meyakininya, seseorang 
perlu mengalami proses pengolahan atas peristiwa dan pengalaman hidup yang berkaitan dengan dirinya maupun dengan orang lain. Ia berbuat baik karena tahu dan yakin akan apa yang ia lakukan melalui pengalaman hidupnya.

Sedangkan Buchari (1994) menjelaskan bahwa antara pengetahuan atau cognition dengan pengalaman atau praxis terdapat suatu jarak yang dapat panjang tetapi dapat pula pendek. Menurutnya, antara mengetahui suatu nilai (termasuk nilai moral dan agama) dengan mengamalkannya terdapat beberapa langkah yang harus dilakukan yaitu; 1) kognisi (cognitio), 2) afeksi (afectio), 3) volisi (volitio), 4) konasi (conatio), 5) motivasi (motivatio), dan 6) praxis atau pengalaman. Pendidikan nilai tidak dapat dilakukan melalui metode ceramah, atau khotbah, atau cerita semata. Karena teknik-teknik yang demikian hanya akan menambah pengetahuan tetapi jarang melahirkan pengamalan.

Sementara itu Lickona menekankan pentingnya memperhatikan tiga unsur dalam pendidikan nilai, yaitu; pengertian atau pemahaman moral, perasaan moral dan tindakan moral. Ketiga unsur ini saling berkaitan. Guru perlu memperhatikan ketiga unsur ini agar nilai-nilai yang ditanamkan tidak sekedar pengetahuan saja, tetapi benar-benar menjadi tindakan yang bermoral/berakhlak (Budiningsih, 2004:6)

Pengertian dan pemahaman moral adalah kesadaran moral, rasionalitas moral atau alasan mengapa seseorang harus melakukan hal itu, suatu pengambilan keputusan berdasarkan nilai-nilai moral. Ini seringkali disebut dengan penalaran moral atau pemikiran moral atau pertimbangan moral, yang merupakan segi kognitif dari nilai moral. Segi kognitif ini perlu diajarkan kepada para siswa. Siswa perlu dibantu untuk mengerti dan memahami mengapa suatu nilai itu perlu dilakukan.
Perasaan moral, lebih pada kesadaran akan hal-hal yang baik dan tidak baik. Perasaan mencintai kebaikan dan sikap empati terhadap orang lain merupakan ekspresi dari perasaan moral. Perasaan moral ini sangat mempengaruhi seseorang untuk berbuat baik. Untuk itu, perasaan moral/akhlak perlu diajarkan dan dikembangkan dengan memupuk perkembangan hati nurani dan sikap empati.

Tindakan moral adalah kemampuan untuk melakukan keputusan dan perasaan moral ke dalam perilaku-perilaku nyata. Tindakan-tindakan moral/akhlak ini perlu difasilitasi agar muncul dan berkembang dalam pergaulan seharihari. Lingkungan sosial yang kondusif untuk memunculkan tindakan-tindakan moral sangat diperlukan dalam pembelajaran moral/akhlak. Ketiga unsur tersebut yaitu, penalaran, perasaan dan tindakan moral harus ada dan dikembangkan dalam pendidikan moral. Selain ketiga unsur tersebut, masyarakat pada umumnya menekankan pentingnya peranan iman atau keyakinan dalam meningkatkan moralitas dan akhlak

Pendidikan nilai tidak hanya berkaitan dengan masalah pertimbangan moral tetapi juga non moral tentang objek yang di dalamnya termasuk estetika (nilai keindahan objek dan selera personal) dan etika (nilai-nilai tentang mana yang benar dan yang salah dalam hal interpersonal yang meliputi konsepkonsep seperti hak asasi manusia, martabat manusia, nilai keadilan, kesamaan, ataupun nilai-nilai yang berhubungan dengan Sang Pencipta seperti nilai-nalai akidah, ibadah maupun akhlak).

Tujuan pendidikan nilai/sikap pada dasarnya adalah untuk membantu peserta didik mengeksplorasi niali-nilai yang ada melalui pengujian yang kritis agar mampu meningkatkan kualitas pikiran dan perasaan dalam mengambil keputusan. Ada empat dimensi dalam pendidikan nilai yaitu (a) identifikasi inti nilai- 
nilai personal, sosial, (b) penemuan filosofis dan rasional tentang inti tersebut, (c) respon afektif atau emotif terhadap inti tersebut, dan (d) pembuatan keputusan berkaitan dengan inti berdasar penemuan dan respon (Somad, 2006).

Pendidikan nilai berkaitan dengan pendidikan afektif. David Krathwohl mengemukakan:"affective aducation is the process of helping students move up the affective hierarchy from the lowest level of receaving value statement up throught the level responding, valuing, organizing a values system, to the highest level of the internalizing a values complex. It is the process of helping students to develop and internalize socially acceptable, morally mature and instructional planning" (Manan dalam Abdul Somad, 2006).

Ungkapan di atas dapat diartikan bahwa pendidikan afektif merupakan proses membantu siswa meningkatkan kualitas afektifnya dari tingkat yang paling rendah pada tingkat yang paling tinggi, yaitu melalui internalisasi suatu nilai melalui beberapa tahap di antaranya tahap menanggapi sampai pada sebuah kemampuan mengembangkan dan menginternalisasikan nilai dan sikap yang matang baik secara moral maupun secara agama yang dapat diterima oleh masyarakat.

Berdasarkan pendapat-pendapat para ahli tersebut maka yang penulis maksud dengan tujuan afektif adalah tujuan-tujuan pendidikan yang berhubungan dengan perasaan, emosi, sistem nilai dan sikap hati (attitude) yang menunjukkan penerimaan atau penolakan terhadap sesuatu.

Dengan demikian pendidikan nilai pada dasarnya penanaman nilai kepada peserta didik sehingga berperilaku sesuai dengan pandangan yang dianggapnya baik dan tidak bertentangan dengan norma-norma yang berlaku. Dalam Pendidikan Agama Islam, nilai yang dimaksud adalah norma-norma dari ajaran
Islam yang bersumber dari Sang Pencipta yaitu Allah Swt.

\section{STRATEGI PEMBELAJARAN PEN- DIDIKAN AGAMA ISLAM (PAI) YANG BERORIENTASI PADA NILAI (AFEKTIF)}

Pendidikan Agama Islam (PAI) di sekolah dan madrasah sebenarnya lebih banyak menonjolkan aspek nilai (afektif), baik nilai ketuhanan maupun kemanusiaan, yang hendak ditanamkan dan ditumbuhkembangkan ke dalam diri peserta didik sehingga dapat melekat pada dirinya dan menjadi kepribadiannya.

Menurut Paul Suparno ada empat strategi pembelajaran nilai (afektif) yang dalam istilahnya pembelajaran moral, yaitu; 1) strategi melalui mata pelajaran tersendiri, 2) strategi terintegrasi dalam semua bidang studi, 3) strategi di luar jam pembelajaran, dan 4) strategi gabungan. Masing-masingnya memiliki kelebihan dan kelemahan. (Asri Budi ningsih, 2004:2) Namun penulis menawarkan empat strategi, yaitu; strategi melalui mata pelajaran tersendiri, strategi terintegrasi dalam seluruh mata pelajaran, penciptaan suasana religius/agamis di sekolah/madrasah dan kerjasama pihak sekolah dengan keluarga dan masyarakat.

\section{Strategi melalui Mata Pelajaran Tersendiri}

Pendidikan sebagai instrumen pemerintah dalam mewujudkan manusia yang beriman dan bertaqwa terhadap Tuhan Yang Maha Esa harus terus dipraktekan oleh guru sebagai ujung tombak keberhasilan proses pendidikan. Salah satu mata pelajaran di sekolah dan madrasah yang sangat mendukung dalam mencapai tujuan tersebut adalah mata pelajaran Pendidikan Agama Islam (PAI).

Pendidikan Agama Islam sebagai salah satu mata pelajaran yang mengandung muatan ajaran-ajaran Islam dan 
tatanan nilai hidup dan kehidupan islami (affektif), perlu dilaksanakan melalui pembelajaran yang efektif. Lalu apa ukuran yang bisa dipakai untuk melihat sebuah kelas atau pembelajaran itu efektif, apakah ukuran hasil belajar, atau ukuran proses belajar. Menurut Hunt (Rosyada, 2004) efektivitas mengajar terkait dengan semua masalah tersebut. Mengajar itu efektif jika pembelajar mengalami berbagai perubahan perilaku dan pengalaman menuju titik akumulasi kompetensi yang dikehendaki.

Pembelajaran nilai melalui mata pelajaran tersendiri harus mempunyai silabus, rencana pelaksanaan pembelajaran (RPP) metodologi dan evaluasi tersendiri dan harus masuk dalam kurikulum dan jadwal yang terstruktur.

Dalam pelaksanaan pembelajaran Pendidikan Agama Islam para guru harus mampu menyentuh emosi/perasaan siswa. Dengan pendekatan emosional ini diharapkan siswa dapat menjadikan agama sebagai bagian dari sikapnya. Agar aspek emosi siswa tersentuh, maka dalam pembelajaran guru harus menggunakan berbagai metode yang ditopang oleh berbagai media. Misalnya pada saat guru mengajarkan sifat saling tolong-menolong dapat diajar melalui pemutaran cuplikan film tentang kondisi para keluarga yang ditimpa gempa, sunami dan sebagainya. Setelah pemutaran tersebut guru dapat mempengaruhi siswa dengan komunikasi yang dapat membuat siswa tersentuh dengan keadaan tersebut.Untuk menunjang pembelajaran ini guru juga perlu membawa para siswa ke lokasi kejadian dan memberikan kesempatan pada siswa untuk mengamalkan pelajaran yang telah didapatnya tentang tolong menolong tersebut.

Kelebihan strategi ini lebih terfokus dan memiliki rencana yang matang untuk menstruktur pembelajaran dan mengukur hasil belajar peserta didik. Strategi ini akan memberikan kesempatan yang lebih luas kepada guru untuk mengembangkan kreatifitasnya. Sedangkan kelemahannya adalah guru bidang studi lain tidak turut terlibat dan bertanggung jawab.

\section{Strategi Terintegrasi Dalam Semua Mata Pelajaran/Bidang Studi}

Bila pembelajaran nilai menggunakan strategi terintegrasi dalam semua bidang studi, maka semua guru adalah pengajar dan pembina nilai tanpa kecuali. Dalam sistem persekolahan, usaha pencapaian aspek affektif/akhlak mulia dapat diintegrasikan ke dalam kurikulum semua mata pelajaran atau bidang studi dengan cara memasukkan nilai-nilai moral pada pokok bahasan, khususnya pada pokok bahasan bidang studi yang mempunyai relevansi sangat tinggi seperti pendidikan budi pekerti, PPKn, bahasa Indonesia, biologi, fisika, matematika, IPS dan lain sebagainya. Model integrasi ini merupakan tugas berat guru, karena ia dituntut tidak hanya berhasil mengantarkan anak didiknya dari aspek kognitif saja, akan tetapi juga dituntut berhasil dari aspek afektif dan psikomotorik.

Dengan pendekatan ini, para guru mengajarkan substansi mata pelajaran atau bidang studinya dengan memberikan nilai-nilai budi pekerti (akhlak) yang terkandung di dalamnya, dengan argumentasi bahwa setiap mata pelajaran pada hakikatnya selalu mengandung dua aspek yang tidak dapat dipisahkan antara satu dengan lainnya, yaitu aspek materi dan aspek nilai. Jika seorang guru atau dosen telah mengintegrasikan keduanya, maka pada hakikatnya ia telah melaksanakan proses pembelajaran dan pendidikan dalam arti yang sebenarnya. Di sinilah salah satu letak kelemahan para guru atau dosen di Indonesia pada umumnya, yaitu lebih mengutamakan pada aspek pengajaran saja dan meninggalkan aspek yang justru lebih penting, yakni pendidikan. Sebagai contoh bagi seorang guru matematika apabila siswa telah menguasai materi pe- 
lajaran sesuai dengan standar kelulusan minimal (SKM) yang telah ditetapkan, berarti tugas telah selesai. Persoalan apakah siswa tersebut tidak melaksanakan ibadah bukanlah tugasnya, tetapi adalah tugas guru agama.

Model pengintegrasian nilai-nilai budi pekerti (akhlak) pada sistem persekolahan dapat dilakukan dalam proses pembelajaran mulai jenjang SD, SMP, SMA sampai perguruan tinggi. Hal ini perlu dilakukan sebagai salah satu tugas profesionalitas guru, yakni mengajar, membimbing, melatih, menfasilitasi, memotivasi, meregulasi, meninspirasi dan sekaligus mendidik anak bangsa menuju kedewasaan berpikir, bersikap dan berperilaku yang dilandasi dan dijiwai akhlak mulia (akhlak al-karimah). Oleh karenanya, dalam praktek pembelajaran, tidak monoton dilakukan dalam bentuk ceramah, melainkan lebih mengutamakan kepada peneladanan diri dan pelatihan serta penenaman akhlak mulia dalam kehidupan sehari-hari.

Integrasi pendidikan budi pekerti sebagai wujud pendidikan berbasis akhlak mulia dalam perencanaan pembelajaran merupakan upaya awal dalam menanamkan nilai-nilai akhlak dalam kegiatan pembelajaran. Upaya ini harus ditindaklanjuti dengan kegiatan pelaksanaan pembelajaran yang memungkinkan tercapainya keterpaduan antara penyajian materi dengan nilai-nilai akhlak mulia. Oleh karena itu, dalam integrasi ini harus dititikberatkan pada aspek sikap dan perilaku, kemudian aspek kognitif. Tujuannya adalah terbentuknya sosok peserta didik yang memiliki karakter dan kepribadian yang dilandasi dengan keimanan dan ketakwaan serta nilai-nilai akhlak yang kokoh yang tercermin dalam keseluruhan sikap dan perilaku sehari-hari.

Pembentukan sikap dan perilaku yang terpuji memerlukan bentuk pembelajaran yang mampu memberikan peluang penghayatan atau internalisasi ni- lai. Berbeda dengan transformasi ilmu pengetahuan yang dapat dilakukan seketika dan sewaktu-waktu, penghayatan atau internalisasi nilai merupakan proses yang memerlukan pengulangan dan kesinambungan. Untuk itu, dalam proses pembelajaran harus memadukan antara penyajian materi dan penerapan nilainilai akhlak yang terpuji dalam kehidupan sehari-hari.

Dalam hal penilaian mengenai akhlak (budi pekerti) anak didik dapat dilakukan guru atau dosen melalui alat penilaian non tes seperti wawancara, pengamatan, skala sikap, dan lain-lain yang memungkinkan guru mendapatkan informasi yang sebanyak-banyaknya dari pihak-pihak yang mempunyai kepentingan dan kepedulian terhadap proses pendidikan.

Kendala pendidikan berbasis akhlak mulia di sekolah adalah paradigma guru dalam mengukur keberhasilan siswa masih banyak yang menitikberatkan pada aspek kognitif saja, sementara aspek afektif dan psikomotorik masih banyak yang dikesampingkan. Di samping itu juga belum siapnya guru atau dosen secara keseluruhan untuk memberikan keteladanan sikap dan perilaku kepada anak didiknya, karena dalam kenyataannya selama ini, guru atau dosen kalau sudah selesai mengajar berarti selesai pula tugasnya, padahal masih ada tugas yang lebih substansial yaitu mendidik melalui keteladanan sikap dan perilaku yang diwujudkan dalam bertutur kata, bersikap, dan bertindak.

Kelebihan strategi ini adalah semua guru bertanggung jawab dan pembelajaran tidak selalu bersifat informatif-kognitif, melainkan bersifat terapan pada setiap bidang studi. Sedangkan kelemahannya adalah jika terjadi perbedaan persepsi tentang nilai-nilai di antara guru, justru akan membuat siswa menjadi bingung. 


\section{Strategi Melalui Penciptaan Suasana Religius di Sekolah/Madrasah}

Disamping strategi melalui mata pelajaran/bidang studi, pencapaian tujuan-tujuan afektif/akhlak juga harus didukung oleh suasana religius/agamis yang ada di sekolah/madrasah. Tanpa terciptanya suasana religious/agamis, maka nilai-nilai yang didapatkan siswa dalam pembelajaran di kelas akan sulit terlaksana, manakala sikap dan perilaku yang diperlihatkan di lingkungan sekolah/madrasah berbeda/bertentangan dengan apa yang dipelajarinya.

Strategi pembelajaran afektif/akhlak lebih mengutamakan pengolahan dan penanaman nilai melalui suatu kegiatan untuk membahas dan mengupas nilai nilai hidup. Peserta didik mendalami nilai-nilai melalui pengalaman-pengalaman konkrit, sehingga nilai-nilai akan tertanam dan terhayati dalam hidupnya.

Banyak hal yang dapat dilakukan dalam menciptakan suasana religius/agamis di sekolah/madrasah, di antaranya; mengadakan kegiatan-kegiatan ekstra kurikuler yang bernuansa keagamaan, melengkapi sekolah/madrasah dengan berbagai sarana dan prasarana keagamaan, dan memberikan contoh teladan tentang sikap dan perilaku yang baik pada siswa.

Penciptaan suasana religius/agamis melalui kegiatan ekstra kurikuler dapat dilakukan antara lain; peringatan harihari besar keagamaan, praktek pengalaman ibadah, lomba-lomba keagamaan, bakti sosial, forum-forum diskusi keagamaan dan sebagainya. Kelemahannya jika pelaksanaan kegiatan-kegiatan tersebut hanya dilakukan setahun sekali atau dua kali, maka kurang memperoleh hasil yang bersifat permanent dan maksimal. Pembelajaran dengan cara ini harus diprogramkan secara rutin dan berkala.

Agar kegiatan-kegiatan ektra kurikuler dapat dilaksanakan secara maksimal perlu didukung oleh kelengkapan sarana dabn prasarana keagamaan, seperti; musholla dengan berbagai fasilitasnya, tempat-tempat pertemuan dan personil-personil pembimbing/pembina kegiatan keagamaan.

Hal lain yang perlu menjadi perhatian dari pihak sekolah/madrasah adalah bagaimana seluruh personil-personil sekolah/madrasah dapat memberikan contoh teladan pada siswa dalam bersikap dan berperilaku. Keteladanan dari personil-personil sekolah akan memperkuat proses internalisasi nilai-nilai afektif/akhlak pada diri siswa. Untuk itu diperlukan kesamaan visi seluruh komponen sekolah/madrasah dalam mewujudkan siswa yang berakhlak mulia.

\section{Strategi Melalui Kerjasama Sekolah dengan Masyarakat dan Orang Tua Siswa}

Para siswa banyak menghabiskan waktu di rumah tangga dan masyarakat. Untuk itu sekolah/madrasah perlu menjalin kerjasama dengan tokoh-tokoh masyarakat dan keluarga siswa.

Di tengah-tengah masyarakat idealnya harus tercermin nilai-nilai moral yang harus tergambar dalam pribadi tokoh agama, tokoh masyarakat, dan masyarakat pada umumnya, sehingga memungkinkan anak didik bisa menjadikan masyarakat sebagai salah satu sumber belajar dan laboratorium penanaman pendidikan akhlak. Akan tetapi idealitas ini terkadang tidak ditemui di masyarakat, apalagi kalau masyarakatnya tergolong acuh tak acuk dengan nilai-nilai ajaran agama dan moral, maka sangat sulit bagi anak didik untuk berharap dapat pendidikan akhlak dari masyarakat. Padahal salah satu basis pendidikan akhlak adalah masyarakat.

Model pendidikan berbasis akhlak mulia di masyarakat dilakukan dengan cara menimba dan menggali nilai-nilai moral yang ada di masyarakat. Masyarakat mempunyai peran penting dalam ikut serta mengantarkan keberhasilan 
anak didik untuk mempunyai sikap dan perilaku terpuji. Masyarakat di sini dalam arti lebih luas, bisa masyarakat umum dan juga bisa tokoh agama atau tokoh masyarakat. Dengan demikian, partisipasi masyarakat akan pendidikan akhlak pada generasi penerus bangsa sangat mutlak dibutuhkan, sehingga konsekuensinya masyarakat juga harus menjadi cermin kehidupan bagi anak didik yang ditunjukkan melalui keteladanan sikap dan perilaku terpuji dari semua komponen masyarakat dalam kehidupan sehari-hari.

Optimalisasi peran masyarakat dalam proses pendidikan sangat membantu sekolah dalam menanamkan nilainilai moral (akhlak), sehingga di sinilah dibutuhkan kerjasama yang baik antara sekolah dengan masyarakat. Adanya komite sekolah merupakan salah satu upaya partisipasi masyarakat terhadap sekolah dan upaya sekolah mendekati masyarakat. Akan tetapi kenyataannya yang sering dibicarakan oleh kedua belah pihak adalah mengenai urusan yang bersifat materi saja seperti biaya sekolah, kebutuhan fisik, bukan hal-hal yang bersifat lebih substansial seperti bagaimana mengantisipasi kemerosotan moral anak didik, apa yang harus dilakukan oleh sekolah, apa yang dilakukan oleh masyarakat, dan lain sebagainya.

Kendala yang ditemui di lapangan dalam membangun pendidikan berbasis akhlak mulia di masyarakat adalah kurang kondusifnya lingkungan dalam masyarakat sendiri seperti 1) masyarakat yang menjadi lingkungan tempat tinggal anak didik kurang peduli terhadap ajaran agama dan nilai-nilai moral, 2) kurang adanya keteladanan dari tokoh agama dan tokoh masyarakat, dan lain-lain.

Di samping kerjasama dengan masyarakat, pihak sekolah juga perlu menjalin kerjasama dengan orang tua siswa (keluarga). Keluarga merupakan satuan unit terkecil dari masyarakat. Ia menjadi 'payung' pertama bagi anak didik, dari keluargalah sebenarnya anak mendapat pendidikan yang pertama kali, karena waktu berinteraksi dalam keluarga juga lebih banyak. Keluarga di sini banyak dimain-perankan oleh ibu-ayah atau orang yang dituakan dalam keluarga. Mereka mempunyai tanggungjawab besar dalam mengantarkan anak-anaknya menjadi generasi penerus yang mempunyai kepribadian luhur (akhlak alkarimah). Ibu-ayah atau orang yang dituakan dalam keluarga merupakan cermin kehidupan bagi anak-anaknya. Kalau mereka menginginkan anak-anaknya menjadi baik, maka ibu-ayahlah yang pertama harus menjadi baik dulu, sehingga di sinilah dibutuhkan keteladanan sikap dan perilaku terpuji dari ibu-ayah atau dari orang yang dituakan dalam keluarga.

Dengan demikian, model pendidikan berbasis akhlak mulia di keluarga agar bisa tercapai secara efektif, maka diperlukan keteladanan atau pemodelan dari orang yang menjadi cermin kehidupan. Ini memang menuntut orang tua untuk menjadi teladan bagi anakanaknya, karena orang tualah yang lebih tahu karakter putra putrinya.

Kendala pendidikan akhlak di keluarga adalah masih banyaknya ibu-ayah atau orang yang dituakan dalam keluarga belum bisa memberikan keteladanan sikap dan perilaku bagi anak-anaknya, sebagai contoh ketika menyuruh anaknya melaksanakan shalat, akan tetapi ia sendiri tidak melaksanakannya. Atau bahkan di dalam lingkungan keluarga tidak kondusif tertanamnya nilai-nilai moral (akhlak) seperti tidak adanya "unggahungguh" antara anak dengan orang tua, terpesona dengan kegemerlapan duniawi, dan lain sebagainya.

Tanggungjawab institusi pendidikan, baik sekolah, masyarakat, maupun keluarga semuanya mempuyai peran dan tanggungjawab yang sama dalam menghasilkan anak didik yang berakhlak mulia, sehingga di sinilah ketiga institusi 
tersebut perlu membangun kerjasama yang baik. Model pendidikan berbasis akhlak mulia yang dilakukan oleh ketiga institusi pendidikan tersebut akan bisa berhasil secara efektif apabila dilakukan melalui pendekatan keteladanan sikap dan perilaku (pemodelan) dari ketiga pioner institusi pendidikan yaitu guru, tokoh agama/tokoh masyarakat, dan orang tua. Akan tetapi dalam kenyataannya, keteladanan sikap dan perilaku (pemodelan) itulah justru yang menjadi kendala bagi pendidikan berbasis akhlak mulia, karena selama ini masih banyak guru, tokoh masyarakat, dan orang tua yang belum bisa menjadi model dan cermin kehidupan bagi anak-anaknya.

Menjadi seorang pendidik tidaklah ringan tanggungjawabnya, karena ia harus siap menjadi seorang 'driver' yang mampu memberikan petunjuk arah dan memilih jalan yang tepat dan sekaligus mampu menerapkannya dalam kehidupan sehari-hari melalui keteladanan, baik keteladanan dalam bertutur kata, bersikap, maupun bertindak secara terpuji.

\section{DAFTAR RUJUKAN}

Ahmad Tafsir, 2007. Ilmu Pendidikan dalam Perspektif Islam, Bandung:Rosda,

Abdul Mudjib, 2006. Ilmu Pendidikan Islam, Jakarta:Kencana,

C.Asri Budiningsih, Pembelajaran Moral Berpijak pada Karakteristik Siswa dan Budayanya, Jakarta: Reneka Cipta 2004

Dede Rosyada, 2004. Paradigma Pendidikan Demokratis, Jakarta :Kencana

W.Gulo, 2005. Strategi Belajar Mengajar, Jakarta:Grasindo

Muhaimin, 2004. Paradigma Pendidikan Islam, Upaya mengefektifkan Pendidikan Islam di Sekolah, Bandung:Rosda Karya

\section{PENUTUP}

Terjadinya fenomena-fenomena pembelajaran Pendidikan Agama Islam di sekolah/madrasah yang lebih menekankan pada aspek kognitif dan mengabaikan espek afektif menyebabkan tujuan Pendidikan Agama Islam tidak maksimal pencapaiannya. Para siswa kaya dengan pengetahuan, namun miskin dengan pengamalan. Untuk mengatasi masalah ini diperlukan berbagai strategi untuk mewujudkan tujuan pendidikan Islam secara utuh termasuk aspek afektif. Ada setidaknya tiga strategi yang dapat dilakukan yaitu: 1) strategi melalui mata pelajaran tersendiri yang sudah biasa dilakukan, 2) strategi melalui pengintegrasian seluruh mata pelajaran/bidang studi 3) strategi melalui penciptaan suasana religius di sekolah/ madrasah dan 4) strategi melalui kerjasama sekolah/madrasah dengan masyarakat dan keluarga siswa.

Muhaimin, 2005. Pengembangan Kurikulum Pendidikan Agama Islam di Sekolah, Madrasah dan PT, Jakarta, Raja Grafindo

Muhktar Buchori, 1994. Ilmu Pendidikan dan Praktek Pendidikan dalam Renungan, Yogyakarta:Tiara Wacana

HM.Chabib Thoha, 1996. Kapita Selekta Pendidikan Islam, Yoyakarta: Pustaka Pelajar,

Wina Sanjaya, 2007. Strategi Pembelajaran Berorientasi Standar Proses Pendidikan, Jakarta: Kencana

Undang-Undang Nomor 20 Tahun 2003 Tentang Sistem Pendidikan Nasional 



\section{Indeks}

afektif, 1, 136, 139, 141, 142, 144

Pendidikan, 1, 136, 138, 139, 140, 144, ahklak, 1 145

nilai, 1, 136, 137, 138, 139, 140, 141, $142,143,144$

strategi, 1, 136, 139, 140, 142, 144

* Poenulis adalah Lektor dalam Mata Kuliah Pendidikan Islam STAIN Batusangkar 